\title{
Synthesis and characterization of one-component, moisture curing polyurethane adhesive based on Rokopol ${ }^{\circledR}$ D2002 (Rapid communication)
}

\author{
Jadwiga Wadas ${ }^{1)}$, Rafał Oliwa ${ }^{1)}$, Barbara Pilch-Pitera ${ }^{2)}$, Łukasz Byczyński ${ }^{2)}$, Maciej Heneczkowski ${ }^{1), *)}$, \\ Zbigniew Florjańczyk ${ }^{3)}$, Andrzej Plichta ${ }^{3)}$, Gabriel Rokicki ${ }^{3)}$
}

DOI: dx.doi.org/10.14314/polimery.2020.7.10

\begin{abstract}
One-part, moisture curing polyurethane (PUR) adhesives based on poly(oxypropylene)diol Rokopol $^{\circledR}$ and 4,4'-diphenylmethylene diisocyanate (MDI) modified with di-isononyl phthalate and a number of inorganic fillers and additives such as carbon black, thixotropic agent, dispersants and dibutyltin dilaurate as curing catalyst were developed. Adhesive curing was followed using dynamic oscillation rheometry and effect of some components on viscoelastic properties of curing materials was discussed. The cured materials were characterized by means of differential scanning calorimetry (DSC) and water contact angle measurements. The adhesive performance of obtained materials in bonding aluminum was evaluated by tensile shear bond strength tests.
\end{abstract}

Keywords: PUR, adhesive, moisture-curing, rheometry, DSC, Al/Al bonding.

\section{Synteza i charakterystyka jednoskładnikowych klejów poliuretanowych na osnowie polieterodiolu Rokopol ${ }^{\circledR}$ D2002}

\begin{abstract}
Streszczenie: Opracowano jednoskładnikowe kleje na osnowie diizocyjanianu 4,4'-metylenodifenylu (MDI) i polioksypropylenodiolu z środkami pomocniczymi (ftalanem diizononylu jako plastyfikatorem, napełniaczami: talkiem, haloizytem, modyfikowanym bentonitem; dyspergatorami, sadzą pigmentową i katalizatorem utwardzania - dilaurynianem dibutylocyny). Proces sieciowania analizowano za pomocą reometru z dynamiczną oscylacją. Metodą różnicowej kalorymetrii skaningowej wyznaczano temperaturę zeszklenia, ponadto określano kąt zwilżania i właściwości adhezyjne otrzymanych materiałów przeznaczonych do łączenia spoin Al/Al.
\end{abstract}

Słowa kluczowe: PUR, kleje, szczeliwa, utwardzanie wilgocią, reometria, DSC, Al/Al, klejenie.

One-component polyurethane moisture curing adhesives and sealants have found widespread use in the automotive and construction market. They key benefits include good adhesion to various materials, flexibility and absorption of stress, high abrasion resistance and high impact resistance. Commercially available products consist of prepolymer containing isocyanate (-NCO) end groups, a plasticizers, catalysts and several fillers and additives. These materials can be easily applied with a standard caulking gun and do not need to be mixed with crosslinking agent prior to application because curing is initiated by contact with moisturized air [1, 2].

\footnotetext{
1) Rzeszow University of Technology, Department of Polymer Composites, al. Powstańców Warszawy 6, 35-959 Rzeszów, Poland.

2) Rzeszow University of Technology, Department of Polymers and Biopolymers, al. Powstańców Warszawy 6, 35-959 Rzeszów, Poland. 3) Warsaw University of Technology, Faculty of Chemistry, Noakowskiego 3, 00-664 Warsaw, Poland.

*) Author for correspondence: mhen@prz.edu.pl
}

Under the influence of water, a part of the -NCO decompose producing an amine group and releasing carbon dioxide as a by-product. In the next step the remaining -NCO group react with the amine forming urea linkages, which leads to a gradual increase in molar mass (Scheme A) [1-3].

Moisture-curing polyurethanes adhesives can offer unique characteristic because of the wide variations in

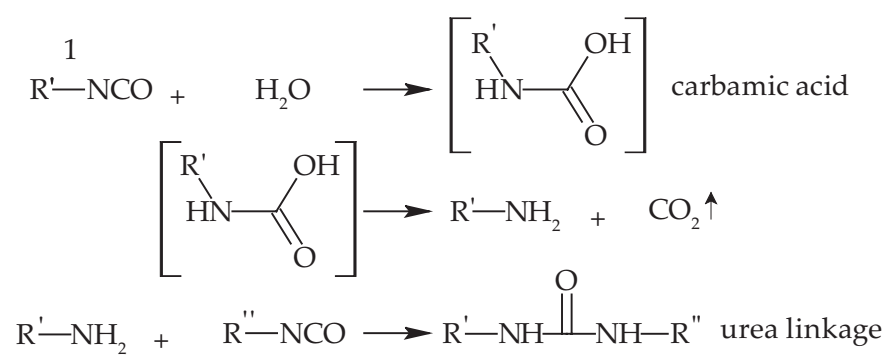

Scheme A. Scheme of curing of one-component PUR adhesive 1 - isocyanate-terminated prepolymer 
physical properties that can be achieved by modifying their formulation. This applies to the properties of the prepolymer itself, the selection of curing catalysts as well as the selection of other components that have a significant impact on the performance of the adhesive composition. The process of composition curing usually is characterized by rheological test that allow to determine the change in the viscosity of the composition as a function of curing time. In this article we will present a results of such research on the example of several compositions obtained in our laboratories. We will also present preliminary results showing the effect of curing on the adhesion properties. In this series of studies, the addition reaction of poly(oxypropylene)diol Rokopol ${ }^{\circledR}$ (D2) with 4,4'-diphenylmethylene diisocyanate (MDI) was used for the synthesis of urethane prepolymer.

\section{EXPERIMENTAL PART}

\section{Materials}

- Poly(oxypropylene)diol (D2), Rokopol ${ }^{\circledR}$ D2002, $\mathrm{OH}$-value $59.6 \mathrm{mg} \mathrm{KOH} / \mathrm{g}, M_{w} \cong 2000$, producer: PCC Rokita S.A. Poland;

- plasticizer: di-isononyl phthalate (iNP), supplier: Brenntag Sp. z o.o., Poland;

- 4,4'-diphenylmethylene diisocyanate (MDI) pure, producer: Acros Organics, Germany;

- dibutyltin dilaurate (DBTDL), producer: Alfa Aesar $\mathrm{GmbH} \& \mathrm{Co}$ KG, Germany;

- toluene pure, producer: Chempur, Poland;

- dispersant: Efka ${ }^{\circledR}$ PU 4050 (E1), modified polyurethane dispersing agent, producer: BASF B.V., Netherland;

- dispersant: Byk ${ }^{\circledR}-\mathrm{W} 966(\mathrm{~W})$, solution of a salt of unsaturated polyamine amides and acidic polyesters, producer: BYK Chemie GmbH, Germany;

- thixotropic agent: bentonite modified with quaternary ammonium salt, Cloisite ${ }^{\circledR} 20$ (B), producer: BYK Chemie $\mathrm{GmbH}$, Germany;
- halloysite $(\mathrm{H})$, filler, producer: PTH INTERMARK, Gliwice;

- talc (T), Steamic ${ }^{\circledR}$ 00S CA, filler, producer: Imerys (France);

- carbon black, black pigment and thickener, producer: Orion Engineered Carbons $\mathrm{GmbH}$, Germany: Printex ${ }^{\circledR} \mathrm{U}$ Powder $-\mathrm{pH}$ Value $=4.5,(\mathrm{C} 1)$, Printex ${ }^{\circledR} 30$ Powder $-\mathrm{pH}$ Value = 9.5, (C2);

- 3-layer (PE/Al/PET) film for sealant packaging bag, producer: MARMA Polskie Folie, Poland.

\section{PUR prepolymer and adhesive preparation}

The procedure for obtaining the adhesive composition consisted of three stages. In the first, a dispersion of fillers, thixotropic agent and carbon black was prepared in the mixture of D2 polyol, plasticizer and dispersant. In particular composition, the type of carbon black and dispersant were changed while maintaining the constant weight proportions of the component used (Table 1).

In the next step, MDI was added to the dispersion and polyaddition reactions were carried out. The molar ratio of functional group - $\mathrm{NCO} / \mathrm{OH}$ was 2.37 (composition M1) or 2.55 (compositions M2-M5). After completion of the reaction, a curing catalyst was added and the adhesives composition was packaged in argon atmosphere into the three layers film welded bag and stored for tests. The detailed procedure is described below.

A reaction vessel $500 \mathrm{~cm}^{3}$ with a 4 necks lid fixed with a mechanical stirrer by stirring lock, and vacum/argon inlet/outlet was dried. Then, polyol (D2), plasticizer (iNP) and E1 or W, according to Table 1 gramms, were added into the vessel, dried under vacuum at $95-105^{\circ} \mathrm{C}$ with the stirrer running. After 2 hours additves (prior dried under vacuum: $<1 \mathrm{~mm} \mathrm{Hg}, 150^{\circ} \mathrm{C}, 12$ hours) (Table 1 : $\mathrm{B}, \mathrm{T}, \mathrm{H}$ and $\mathrm{C} 1$ or $\mathrm{C} 2$ ) were added to the vessel and mixed for $30 \mathrm{~min}$ at $70^{\circ} \mathrm{C}$ and MDI was diluted in plasticizer (iNP) (Table 1) and added into reaction vessel at $60^{\circ} \mathrm{C}$ with the stirrer running. Reaction was carried out at $70 \pm 2^{\circ} \mathrm{C}$ for $\sim 2$ hours. Reaction

$\mathrm{T}$ a b l e 1. Composition of studied polyurethane blends

\begin{tabular}{|c|c|c|c|c|c|}
\hline \multirow{2}{*}{$\begin{array}{c}\text { Blend } \rightarrow \\
\downarrow \text { Component }\end{array}$} & M1 & M2 & M3 & M4 & M5 \\
\hline & \multicolumn{5}{|c|}{ Content, g } \\
\hline D2 & 106.2 & 106.2 & 106.2 & 106.2 & 106.2 \\
\hline iNP & 45.0 & 45.0 & 45.0 & 45.0 & 45.0 \\
\hline MDI & 29.7 & 31.9 & 31.9 & 31.9 & 31.9 \\
\hline E1 & 0.4 & 0.4 & - & 0.4 & - \\
\hline W & - & - & 0.4 & - & 0.4 \\
\hline B & 4.2 & 4.2 & 4.2 & 4.2 & 4.2 \\
\hline $\mathrm{T}$ & 44.5 & 44.5 & 44.5 & 44.5 & 44.5 \\
\hline $\mathrm{H}$ & 29.7 & 29.7 & 29.7 & 29.7 & 29.7 \\
\hline $\mathrm{C} 1$ & 3.2 & 3.2 & 3.2 & - & - \\
\hline $\mathrm{C} 2$ & - & - & - & 3.2 & 3.2 \\
\hline DBTDL & 2.5 & 2.5 & 2.5 & 2.5 & 2.5 \\
\hline
\end{tabular}


completion was confirmed by final NCO concentration determined after reaction with an excess of dibutylamine and titration of unreacted amine with hydrochloric acid. At the end of the reaction mixture was cooling to $40^{\circ} \mathrm{C}$ and $2.5 \mathrm{~g}$ of DBTDL was added and diluted in $8.5 \mathrm{~g}$ moisture free toluene and mixed for some minutes.

\section{Methods fo testing}

For prepared adhesives rheological tests, the tensile shear bond strength measurements for aluminum joints, water contact angle and DSC studies of cured samples were performed.

The rheological tests were carried out by dynamic oscillation using a rheometer Discovery HR-2: oscillation frequency $-1 \mathrm{~Hz}$, deformation $-0.2 \%$, for $25 \mathrm{~mm}$ diameter aluminum parallel plates tools and measuring gap $-1 \mathrm{~mm}$. PUR adhesive was dropped into the measuring plate and it was conditioned under moisturized air (45-55\% relative humidity) for $2 \mathrm{~min}$. After that the plate was placed in instrument for measurement start. The tests were performed at three temperatures: 25,35 and $45^{\circ} \mathrm{C}$ with thermal stability $0.1^{\circ} \mathrm{C}$.

The tensile shear bond strength was measured according to Standard PN EN 1465:2009 with an Instron 5967 (USA) at a tensile speed of $5.0 \mathrm{~mm} / \mathrm{min}$. During this test, shear stress was applied across the adhesive bond, and the bonded materials were forced to slide over each other with the adhesive bond layer providing the resistive force. The substrates for the tensile shear bond strength measurements are aluminum (Al) plates $20 \times 100 \mathrm{~mm}$ and thickness $2.0 \mathrm{~mm}$. Each plate was adhered with prepared adhesive the bonded test pieces were aged at $23^{\circ} \mathrm{C}$ under $50 \%$ relative humidity for minimum 48 hours. The $\mathrm{Al}$ joints were conditioned at room temperature for 4 days.

For water wetting angles measurements instrument OCA15 Pro (producer DataPhysics Instruments $\mathrm{GmbH}$, Germany) was used. Liquid drop volume $-0.05 \mathrm{~cm}^{3}$, temperature $22 \pm 1^{\circ} \mathrm{C}$. Results were analyzed with computer program SCA20U.

Differential scanning calorimetry (DSC) method using DSC $822^{\mathrm{e}}$ with computer program Star ${ }^{\mathrm{e}}$ System (producer Mettler Toledo, Switzerland) was used to study thermal properties of adhesives. Studies parameters: temperature range: $-100-50^{\circ} \mathrm{C}$, heating/cooling rate $10 \mathrm{deg} / \mathrm{min}$, runs: heating, cooling, heating, glass temperature $\left(T_{g}\right)$ midpoint determination.

\section{RESULTS AND DISCUSSION}

Rheometric tests of cured compositions allowed observation of changes of viscoelastic parameters such as shear storage modulus $\left(G^{\prime}\right)$, loss modulus $\left(G^{\prime \prime}\right)$, complex viscosity $\left(\eta^{*}\right)$ and estimate the gel time $\left(t_{g}\right)$ (at the point when $G^{\prime}=G^{\prime \prime}-$ Fig. 1).

The dependence of gel time on temperature meets the Arrhenius equations (1, 2) [4-9] and the curing activation

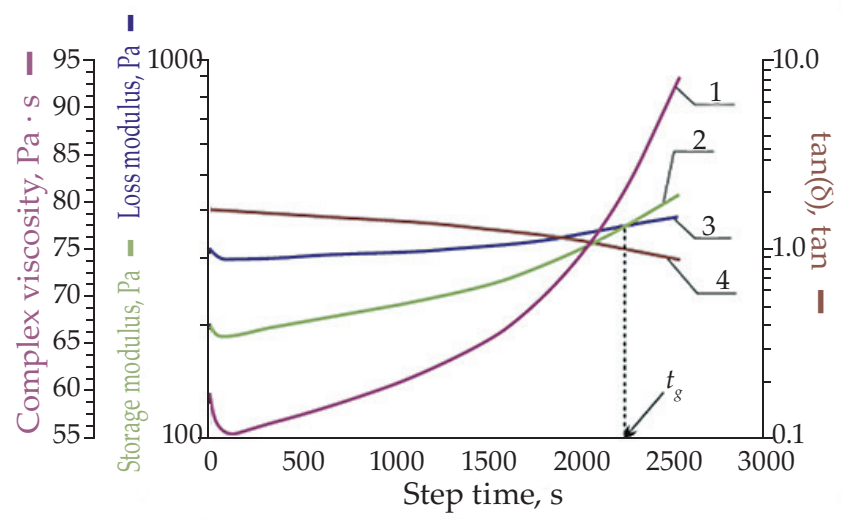

Fig. 1. Rheometric curves of PUR adhesive sample M1 studied at $25^{\circ} \mathrm{C}: 1$ - complex viscosity $\left(\eta^{*}\right), 2$ - storage modulus $\left(G^{\prime}\right), 3$ - loss modulus $\left(G^{\prime \prime}\right), 4$ - loss factor $(\tan \delta) ; t_{g}$ - gel time

energy $E_{a \eta}$ was determined from the plot of $\ln t_{g}$ versus $1 / \mathrm{T}$.

$$
\begin{gathered}
t_{g}=t_{\infty} e^{E_{a_{\eta}} / R T} \\
\ln t_{g}=\ln t_{\infty}+\frac{E_{a \eta}}{R} \cdot \frac{1}{T}
\end{gathered}
$$

where: $t_{\infty}-$ constant (reference gel time at "infinite temperature"), $E_{a \eta}$ - curing activation energy, $R$ - universal gas constant, $T$ - absolute temperature.

The determined gel times and curing activation energies are presented in Table 2.

The table includes also the values of the initial viscosities of the tested compositions, as well as the viscosities and modules $G^{\prime}=G^{\prime \prime}$ at the gel point.

The obtained results allow to assess the influence of some components on the viscosity of the produced materials and the process of their curing. Comparing the data for samples M1 and M2, we can see that increasing the MDI content leads to a significant reduction in the viscosity of the adhesive and the cured material. The reason for this is the lowering of the prepolymer molar mass as the concentration of $-\mathrm{NCO}$ groups increases. The M2 composition containing the lower molar mass prepolymer is also characterized by lower curing activation energy and longer gel time. It is also seen that the type of carbon black used has a significant impact on the viscosity of resulting compositions. M4 and M5 compositions containing alkaline carbon black (C2) have higher viscosity than M2 and M3 ones with acidic carbon black (C1). In these systems, carbon black acts as a pigment and thickener and probably the alkaline centers on its surface promote stronger interactions with prepolymer. This leads to longer gel time and an increase in the activation energy of this process. The effect of $\mathrm{C} 2$ on the viscosity of the composition depended on the type of dispersant use and was particularly large in system containing $\mathrm{C} 2$ and dispersant Efka ${ }^{\circledR}$ PU 4050 (E1). The influence of the type of dispersant on the rheological properties of compositions containing C1 (M2 and M3) was much smaller, and some 
T a b l e 2. Results of chemorheometric tests of studied polyurethane adhesives

\begin{tabular}{|c|c|c|c|c|c|c|}
\hline Sample & $\begin{array}{c}\text { Temperature } \\
{ }^{\circ} \mathrm{C} \\
\end{array}$ & $\begin{array}{c}\text { Start viscosity } \\
\mathrm{Pa} \cdot \mathrm{s}\end{array}$ & $\begin{array}{c}\text { Gel time, } t_{g} \\
\mathrm{~s}\end{array}$ & $\begin{array}{c}\text { Modules at } t_{g^{\prime}} G^{\prime}=G^{\prime \prime} \\
\mathrm{Pa}\end{array}$ & $\begin{array}{c}\text { Viscosity at } t_{g} \\
\mathrm{~Pa} \cdot \mathrm{s}\end{array}$ & $\begin{array}{c}E_{a \eta} \\
\mathrm{J} / \mathrm{mol}\end{array}$ \\
\hline \multirow{3}{*}{ M1 } & 25 & 60 & 2240 & 358 & 81 & \multirow{3}{*}{9.94} \\
\hline & 35 & 37 & 820 & 199 & 45 & \\
\hline & 45 & 23 & 200 & 108 & 24 & \\
\hline \multirow{3}{*}{ M2 } & 25 & 18 & 3200 & 186 & 42 & \multirow{3}{*}{7.14} \\
\hline & 35 & 14 & 1200 & 90 & 20 & \\
\hline & 45 & 9 & 600 & 50 & 11 & \\
\hline \multirow{3}{*}{ M3 } & 25 & 21 & 2200 & 183 & 41 & \multirow{3}{*}{5.74} \\
\hline & 35 & 13 & 1100 & 100 & 23 & \\
\hline & 45 & 10 & 600 & 64 & 14 & \\
\hline \multirow{3}{*}{ M4 } & 25 & 66 & 4100 & 694 & 156 & \multirow{3}{*}{15.07} \\
\hline & 35 & 36 & 800 & 269 & 61 & \\
\hline & 45 & 18 & 100 & 97 & 22 & \\
\hline \multirow{3}{*}{ M5 } & 25 & 22 & 4100 & 282 & 63 & \multirow{3}{*}{7.96} \\
\hline & 35 & 14 & 1700 & 136 & 31 & \\
\hline & 45 & 11 & 600 & 78 & 17 & \\
\hline
\end{tabular}

T a b l e 3. Properties of cured PUR adhesives

\begin{tabular}{c|c|c|c}
\hline Sample & $\begin{array}{c}\text { Tensile shear } \\
\text { bond strength of } \\
\mathrm{Al} / \mathrm{Al}, \mathrm{MPa}\end{array}$ & $\begin{array}{c}\text { Water contact } \\
\text { angle } \\
\text { deg }\end{array}$ & $\begin{array}{c}\text { Glass } \\
\text { temperature } \\
T,{ }^{\circ} \mathrm{C}\end{array}$ \\
\hline M1 & $1.59 \pm 0.28^{\mathrm{b}}$ & $92 \pm 1$ & -59.2 \\
M2 & $1.93 \pm 0.31^{\mathrm{b})}$ & $92 \pm 2$ & -58.8 \\
M3 & $\left.1.49 \pm 0.28^{\mathrm{b}}\right)$ & $92 \pm 1$ & -58.6 \\
M4 & $0.70 \pm 0.21^{\mathrm{a} / \mathrm{b})}$ & $93 \pm 1$ & -58.0 \\
M5 & $0.79 \pm 0.31^{\text {a) }}$ & $92 \pm 1$ & -58.7 \\
\hline
\end{tabular}

a) adhesion failure, ${ }^{\text {b) }}$ cohesion failure, ${ }^{\mathrm{a} / \mathrm{b})}$ adhesion/cohesion failure

parameters such as the values of $G^{\prime}$ and $G^{\prime \prime}$ modules and the gel point viscosity were practically the same.

The adhesive properties of cured compositions were compared on the basis of the tensile shear bond strength of $\mathrm{Al} / \mathrm{Al}$ joints (Table 3).

Almost all joints were damaged by cohesion failure, i.e. as a results of delamination within adhesive layer. The values of the tested parameters for M1, M2 and M3 compositions are within 1.5-2.0 MPa while for M4 and M5 are on the level $0.7-0.8 \mathrm{MPa}$, which confirms the adverse effect of alkaline carbon black on the curing process. The M2 composition seems to have the best performance because it has the lowest viscosity and forms joints with the highest mechanical strength. On the other hand the formulation of adhesive does not affect the glass transition temperature of cured materials and their wettability (Table 3). They exhibit elastic properties down to about $-58^{\circ} \mathrm{C}$ and have moderately hydrophobic surface.

\section{CONCLUSIONS}

One-component PUR adhesives were prepared by reaction of poly(oxypropylene)diol $\left(M_{w} \cong 2000 \mathrm{~g} / \mathrm{mol}\right)$ with MDI in the presence of di-isononyl phthalate as plasticizer, talc and halloysite as fillers, Efka ${ }^{\circledR}$ PU 4050 or BYK ${ }^{\circledR}$ W966 as dispersant, modified bentonite Cloisite ${ }^{\circledR} 15$ as thixotropic agent and carbon black of acidic character (Printex ${ }^{\circledR} \mathrm{U}$ Powder) as pigment and thickener. The compositions obtained cure with air moisture at room temperature and form elastic joints of high adhe- sion to aluminum. Alkaline carbon black (Printex ${ }^{\circledR 3} 30$ Powder) was found to have an adverse effect on gel time and adhesive properties of studied compositions.

\section{ACKNOWLEDGMENT}

The authors gratefully acknowledge support from the National Centre for Research and Development (Grant POIR.04.01.01-00-0002/16-01)

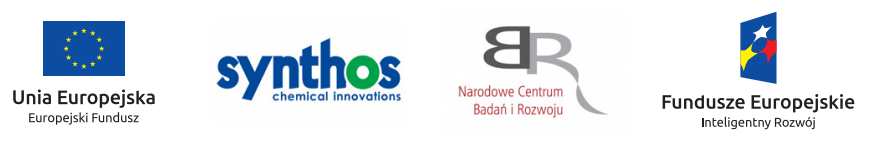

\section{REFERENCES}

[1] Prociak A., Rokicki G., Ryszkowska J.: „Materiały poliuretanowe", Wydawnictwo Naukowe PWN, 2016, Warszawa.

[2] http://digitalcollections.library.cmu.edu/awweb/ awarchive?ty $\mathrm{pe}=$ file\&item $=488891$.

[3] Clauß S., Dijkstra D.J., Gabriel J. et al.: Journal of Applied Polymer Science 2012, 124, 3641. http://dx.doi.org/10.1002/app.35223

[4] Lucio B., de la Fuente J.L.: Thermochimica Acta 2014, $596,6$.

[5] Dunjic B., Djonlagic J., Vukasinovic S. et al.: Journal of the Serbian Chemical Society 2003, 68 (3), 147.

[6] Lucio B., de la Fuente J.L.: Polymer 2018, 140, 290. https://doi.org/10.1016/j.polymer.2018.02.058

[7] Samper M.M., Ferri J.M., Carbonel-Verdu A. et al.: eXPRESS Polymer Letters 2019, 13 (5), 407.

[8] Halley P.J., Mackay M.E., George G.A.: High Perform Polymers 1996, 36 (5), 593. https://doi.org/10.1002/pen.10447

[9] Zhang Q., Huang X., Wang X. et al.: Polymer 2014, 55, 1282.

http://dx.doi.org/10.1016/j.polymer.2014.01.040

Received 10 IV 2020. 